InVisible Culture • Issue 31: Black Studies Now and the CounterCurrents of Hazel Carby

\title{
Black Studies in the Digital Crawlspace
}

\section{Darren Mueller ${ }^{1}$}

${ }^{1}$ University of Rochester

Published on: Nov 15, 2020

DOI: $10.47761 / 494 \mathrm{a} 02 \mathrm{f} 6.63 \mathrm{ec} 3895$

License: Creative Commons Attribution 4.0 International License (CC-BY 4.0). 


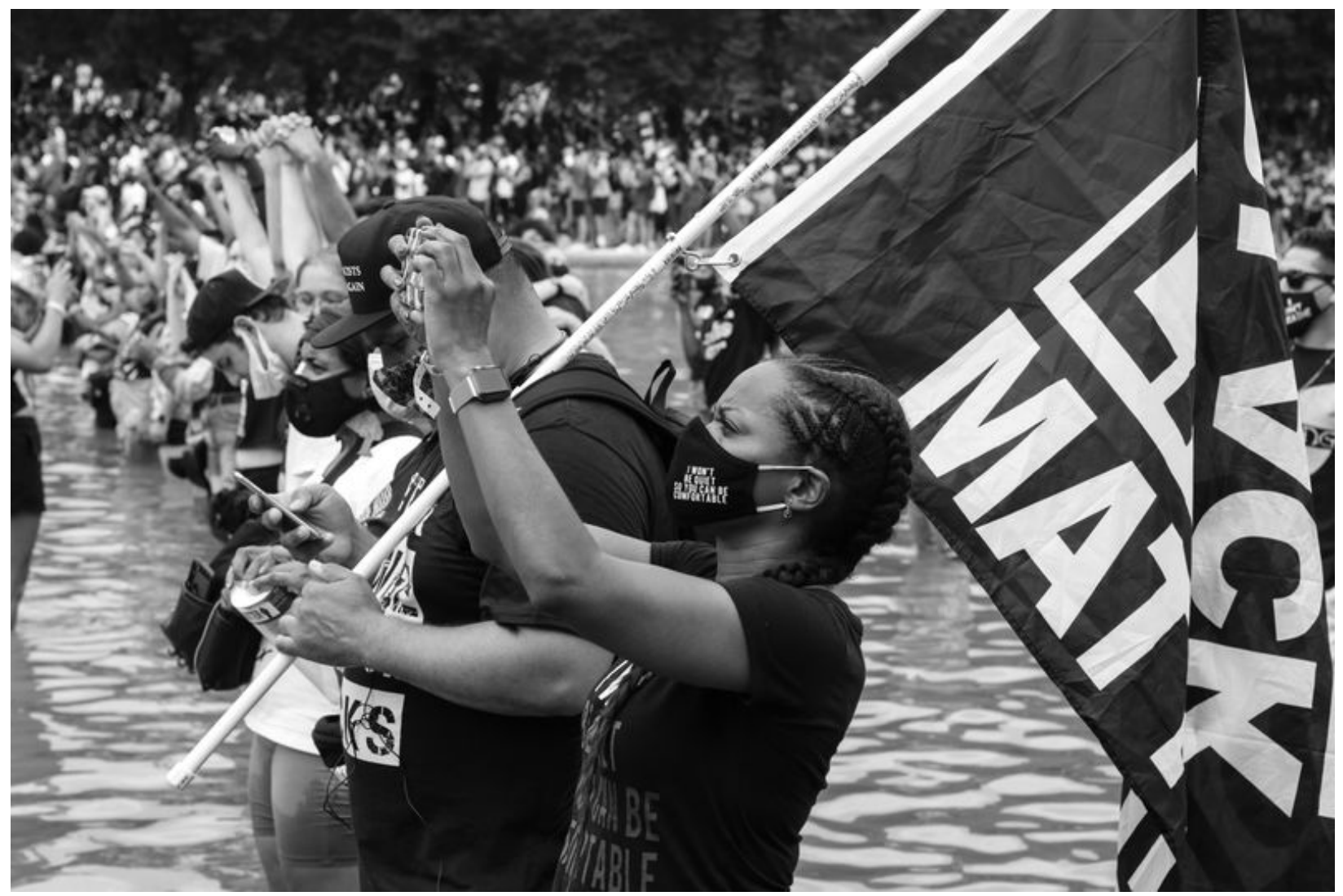

I won't be quiet so you can be comfortable, Washington DC, August 2020, Copyright Erica Jae.

\section{Let our rejoicing rise}

High as the listening skies,

Let it resound loud as the rolling sea.

-James Weldon Johnson, "Lift Every Voice and Sing”포

Listen to pianist Jaki Byard. About seven minutes into Charles Mingus's lengthy 1964 performance of "Fables of Faubus," Byard's solo emerges out of the slowly decelerating ensemble. He jumps from the dramatic to the playful to the playfully dramatic through quotation, interweaving a number of quick ascending scales between melodic fragments of "Yankee Doodle Dandy." Dannie Richmond's snare drum echoes Byard's revolutionary invocation (7:30). Rather than the expected resolution to "Yankee Doodle," Byard instead seamlessly transitions into "Lift Every Voice and Sing." Despite his hymn-like recitation, he dwells in restlessness. A few virtuosic flourishes travel into the highest range of his instrument (7:55) as if echoing the first stanza of James Weldon Johnson's poem: "Let our rejoicing rise / High as the listening skies." Eventually, Byard transitions back into a halting, even stuttering version of 
"Yankee Doodle." Again, he ends in misdirection, through a quotation of Frédéric Chopin's funeral march (8:09). $\underline{2}$ By this time, the ensemble has once more joined together. $\underline{3}$

My listening is likewise a quotation. In Jazz as Critique, Fumi Okiji analyzes Byard's playful yet multilayered performance on "Fables of Faubus" as a statement about the sociomusicality of Black life. Blackness is always a social marker, she writes, and so Black life "cannot help but be lived as critical reflection." 4 Because the boundaries of Black humanity are always caught in the (im)possibilities of performance, she goes on, jazz exposes the political reality of the everyday. That is to say: Byard knew what he was doing. After all, Mingus wrote "Fables of Faubus" as a direct response to Arkansas governor Orval Faubus's notorious (and unlawful) refusal to desegregate Little Rock Central High School in 1957. $\underline{5}$ In Byard's hands, the interwoven quotations of "Yankee Doodle" and "Lift Every Voice" speak to the seriousness of Black resistance and Black belonging to a nation founded on Black enslavement. "Lift Every Voice" is, of course, also known as the Black national anthem-thus, Byard's juxtaposition of that melody with "Yankee Doodle" imagines an alternate mode of being and belonging. $\underline{6}$ Okiji asks us to hear Byard's quotations as inseparable from the sociopolitical struggle over Black personhood.

My listening is not just a quotation, but a digital echo. I recently returned to Okiji's analysis of Byard's performance after reading Erica Ball's review of We Forever Stand: A History of the Black National Anthem by Imani Perry. Ball's July 4, 2019 post appeared on Black Perspectives, the blog of the African American Intellectual History Society (AAIHS). $\underline{7}$ Timed for Independence Day, the review was an occasion to think about the anthem's power across history and consider how citizenship is always multiple but rarely even. It was also an invitation to again engage with Perry's work, including her active (and essential) Twitter profile. My own return to Perry's writing through a blog post mirrored my return to Byard's performance, which I accessed through a digital streaming service designed to encourage musical connections. A simple keyword search created a path for my listening session. I traveled from Mingus to the Boys Choir of Harlem and Jazzmeia Horn. The latter led me even further, to versions by Cyrus Chestnut, Wycliffe Gordon with Eric Reed, Charles Lloyd, Geri Allen, Nnenna Freelon, René Marie, Les McCann, and Art Blakey.

While listening, I began to reflect on the increased circulation of the Black musical archive through such digital infrastructures. $\underline{8}$ I began to wonder about these jazz 
musicians and their decision to perform "Lift Every Voice." I began to question why I had, to this point, failed to hear these versions, even though I devote most of my scholarly attention to the political aurality of jazz. Encouraged by Jaki Byard, I began challenging myself to re-hear this music as a statement of alternate belonging.

This chain of events-from book to blog and down the digital rabbit hole of music history-represents the possibilities of the information age. Knowledge can be a snowball, where print and digital entwine to bring not only the who, what, when, and where of history into view, but also perspectives beyond one's own background. For me, "Lift Every Voice" was a lacuna of cultural knowledge rather than a recurring anthem. So, this kind of digital connectivity forced me to listen again, compelling me to think differently about what it means and feels like to belong. The assemblage made possible by the flow of information through various platforms, devices, technologies, and digital spaces can, in other words, encourage what Jonathan Stone usefully describes as a digital humanity. $\underline{9}$ Jaki Byard's citational reimagining of "Lift Every Voice" is but one entry point.

Challenging the definitions of humanity through an examination of the structures of knowledge production is a central theme within Black Studies. For generations, this body of literature has demonstrated how personhood is pervasively and implicitly understood as white and male, offering Blackness as both a critique and a way to make legible new genres of being human. $\underline{10}$ This intellectual trajectory would not have been possible without Black feminists like Hazel Carby, whose voice echoes across Black music studies. Her consideration of Black female sexuality and new forms of communal expression in the recorded performances of 1920s blues vocalists, for example, reverberates through the work of Angela Davis, Daphne Brooks, Farah Jasmine Griffin, Tammy Kernodle, and Paige McGinley. 11 In The Kind of Man I Am, a monumental examination of Charles Mingus from 2017, Nichole Rustin-Paschal similarly reframes some key interventions from Carby's Race Men; Rustin-Paschal's concept of "black jazzmasculinity" challenges the prevailing notions of genius, genre, and gender that dominate jazz historiography. $\underline{12}$ To generalize Carby's sonorous presence in digital parlance, \#blacklivesmatter cannot be understood apart from \#citeblackwomen. $\underline{13}$ In the information age, Black Studies continues to strategically destabilize assumed notions of identity in order to argue for the multiplicity of personhood. The incredible presence of Black Studies in digital spaces, however, presents a new set of challenges. Imagining alternative forms of belonging through relentless demands for equity and equality is a practice replete with danger. The same technologies that have allowed the 
highly developed modes of thinking, writing, making, arguing, and community-building in Black Studies have also created devastating forms of anti-Black thought and IRL violence. $\underline{14}$ To help think through the relationship between possibility and danger, it will be helpful to consider a crawlspace from the nineteenth century.

\section{Life in the (Digital) Crawlspace}

Another site of listening: Spike Lee's Do the Right Thing. The 1989 film similarly opens with "Lift Every Voice and Sing," played by a solo saxophone during the title credits. An abrupt musical transition to Public Enemy's "Fight the Power" reflects the visual shift on-screen to the streets of Brooklyn. As Mark Anthony Neal understands it, the transition from one type of anthem to another (from hymn to hip hop) represents a generational shift in the sounds of Black resistance. $\underline{15}$ Within the framing of the film's soundtrack, Neal presents the idea of the Black musical archive: a widely circulating musical network that made Black resistance legible in multiple registers. Some forms of music, like "Fight the Power," performed this resistance through pointed lyrics and sound. Others, like "Lift Every Voice and Sing," insisted on equality through uplift and community. Yet both musical examples exist within a public archive that makes space for Black subjectivity within a society built to render Blackness illegible. $\underline{16}$

A number of scholars, including Hazel Carby, use the writing of Harriet Jacobs to theorize about the creation of Black spaces within the confinements of a white hegemony. In her 1861 memoir, Incidents in the Life of a Slave Girl, Jacob's explicates the violences of slavery through her many forms of escape: escape from the unwanted sexual advances of her owner (Dr. Flint), escape to her freedom in New York, and her escape from how chattel slavery singularly defined her as property rather than as human. Before reclaiming her freedom in the north, however, she first escaped into a crawlspace in her grandmother's house. There she had no light, no room to stand, and little contact with her two young children, although she could observe them through the cracks in the floorboards. She lived in this crawlspace for seven years. $\underline{17}$

For Fred Moten, Jacobs's crawlspace offers an opportunity to examine the confinements and freedoms of Black life, both contemporary and historical. $\underline{18}$ Moten understands Jacobs's decision to escape into confinement as an act of "radical flight," thereby transforming the crawlspace into a space of resistance rather than fugitivity. It is a place of (and to) escape where Jacobs "consents not to be a single being." 19 By exerting the power to withhold and disappear, she redefines her own humanity and reclaims her own sense of motherhood. $\underline{20}$ There, she resists the terms set by the slave 
owner and the systems of thought that maintain his power. Nevertheless, danger constantly lurks in the untimely sneeze or accidental creak of the floorboards. Stillness is survival. As such, the crawlspace is a useful allegory because Black life is always under continuous threat and can only be defined through the condition of precarious escape (like Jacobs). To escape into the crawlspace, then, is to intentionally embrace a radical existence against the violence of slavery. $\underline{21}$

Although chattel slavery has not been lawful since the nineteenth century, violent forms of inequality and oppression continue to be maintained. From the killing of unarmed Black citizens by police to voter suppression, and from mass incarceration to the alarming morality rate of expectant Black mothers, dangerous forms of inequality suffuse communities of color. $\underline{22}$ Such threats have also become a feature of digital culture, under different names and through different mechanisms. A deep well of current scholarship shows how digital information technologies are used to limit access to social services and low home-interest rates, spread disinformation, determine gerrymandered district lines, negatively influence policies about homelessness and job creation, reinforce racial stereotyping, increase racial profiling and police surveillance (leading to more arrests), and increase the potential for crippling fraud investigations. In different ways, digital data have come to increasingly structure our social relationships and cultural geography through algorithmic modeling, machine learning, predictive computing, artificial intelligence, and various forms of automation. Safiya Umoja Noble describes this collection of practices as algorithmic oppression; Ruha Benjamin labels it the New Jim Code. Regardless of its description, the organization of society that assumes whiteness as a default has already made the digital turn. The effects have been devastating, pervading banks, schools, hospitals, social service agencies, court rooms, police stations, shopping malls, grocery stores, voting booths, and real estate offices (to name a few examples). $\underline{23}$ The crawlspace remains because digital culture was never designed for equality of life.

Old mechanisms for disenfranchisement have become dressed in the innovations of the digital economy, hidden beneath layers of seemingly neutral digital infrastructures. This is not an abstract issue in the cloud. The organization of such information increasingly disadvantages already oppressed populations by maintaining racial hierarchies. At stake here is not just equitable public policy, but the boundaries of humanity - that is, whose safety is prioritized and whose life is valued. Whiteness and maleness continue to be the default settings of the internet, enabling white supremacy to maintain its hold; anti-Black ideology is not a bug but a feature of algorithmic 
oppression. Constant constraint continues, despite the new forms of stillness (looking at screens) and motion (wireless connectivity). Within what I will call the digital crawlspace, many continue to argue forcefully for their value and to define personhood by their own terms. As an analytic, the notion of the digital crawlspace makes visible those who, like Jacobs, create and maintain space to resist the confinements of a white (digital) hegemony.

Extending the idea of the crawlspace into online space foregrounds the relationship between digital knowledge production and the definitions of Black life. Black Studies continues to thrive despite many constraints, those both hidden and in plain view. The digital crawlspace presents an opportunity to understand how a history of resistance and redefinition moves online. By listening to these escape artists, what else is it possible to hear?

\section{Possibilities in the Digital Crawlspace}

The constant state of interconnection can create a bewildering effect, where the sheer volume of online information leads to digital burnout. $\underline{24}$ The lack of a central gatekeeping mechanism that enables such informational interconnection, however, also creates space for experimental work seeking to restore Black humanity. $\underline{25}$ As a result, an enormously diverse set of creators are building new kinds of digital archives, writing reparative histories, pushing against dominant narratives, and imagining new forms of scholarship. This intellectual work circulates multiple perspectives on Blackness, integrating queer, feminist, transnational, and multiethnic points of view. These projects emerge from both a need to tell such stories and the ability to easily circulate them. In short, the multivalence of Black Studies thrives online.

Music has always been an essential mode of Black expression within a culture defined by whiteness. Black musicians have always emerged from the crawlspace to imagine different ways of knowing and being. The scholarly work surrounding such sonic artistry likewise continues to materialize out of the digital crawlspace in order to recover, redefine, and restore humanity in diverse ways. Here, I would like to offer a way to think about the multiplicity of this output through a few specific examples that point to broader trends. $\underline{26}$

Within the digital ecosystem, existing structures and widely available platforms make the digital work of Black Studies possible. Consider Regina N. Bradley's Outkasted Conversations, a video series begun in February 2014 about African American popular culture through the lens of Southern U.S. hip hop. $\underline{27}$ While the project now has a new 
online home, complete with a supplemental bibliography and list of pedagogical resources, Bradley initially distributed Outkasted Conversations on YouTube. $\underline{28}$ Relatedly, Tara Rogers founded her website "Pink Noises" in 2000 to bring attention to women in electronic music. Black music and musicians are part of her larger story about the diversity of feminist music-making. Eventually Rogers archived the website and moved onto Facebook in order to grow a digitally connected community. $\underline{29}$ This Facebook page remains active-indeed, it was this page that made me aware of Bradley's newest iteration of Outkasted Conversations.

The internet was not built for Black Studies, but creators in this intellectual space have leveraged existing platforms to their advantage. This generalized point is clearly observable in Outkasted Conversations. However, it is less obvious with similar projects that highlight the social and political import of Black music. For example, WordPress is the underlying content management system for many projects, including the SNCC (Student Nonviolent Coordinating Committee) Legacy Project's One Person, One Vote, AAIHS's blog Black Perspectives, and Black Grooves, published monthly by Indiana University Archives of African American Music and Culture. $\underline{30}$ The reasons for such reliance on existing digital infrastructure are not especially complicated:

WordPress makes it relatively easy to build an effective and functional, yet aesthetically pleasing, website with multiple contributors. But it is also true that Black Studies, out of necessity, has always created alternative spaces through already existing structures. The knowledge-making of Black Studies has come to circulate through the digital ecosystem by strategically transforming and redefining public space.

Iteration is another strategy that builds community around the intellectual interventions of Black Studies. One example is Left of Black, a web series hosted by Mark Anthony Neal through the John Hope Franklin Center at Duke University. The series features conversations with authors, academics, and different artists about Black life. Given Neal's own work, it is unsurprising that music is a significant through line. Bradley appeared in April 2017 (S7:E21). Jazz pianist Jason Moran was on in May 2019 (S9: E24). Hip hop artist 9th Wonder (Patrick Douthit) is a regular co-host. $\underline{31}$ Selfdescribed as "black studies for a mobile digital network," Left of Black similarly makes use of existing infrastructures. Its 300 videos (and counting) are all on YouTube; Neal uses Tumblr, a microblogging site, to compile and frame the project. To promote and share this "contrarian view of blackness," as the subtitle declares, Neal expertly uses Facebook and Twitter to communicate with an immense network of followers. $\underline{32}$ 
Left of Black is built for the information age. Through the project, Neal has created an intentionally networked archive that foregrounds the multiplicity of Black thought. It offers intellectual perspectives on history, politics, activism, popular culture, religion, and identity (among many others) not only to document but also to build community. Existing digital infrastructures are essential to this work. But so are iteration and redundancy. Beyond his use of social media, Neal has twice published pieces about music and Black popular culture on Black Perspectives. These articles not only connect Neal's own work with Left of Black to the digital activities of African American Intellectual History Society, but they also join a wider conversation on the AAIHS blog about Black music from jazz to modern pop, from hip hop to Southern roots music, and from soul to classical music. $\underline{33}$ Never before has information about Black music from different time periods, intellectual traditions, and vantage points so easily circulated. This kind of networked connection makes and holds space for Black Studies to exist.

While many of these projects appear to be born digital, they also extend from methods and genres of traditional scholarship. A site like Black Perspectives contains book reviews, interviews, opinion pieces, timely reactions to current events, and historical correctives. Mark Anthony Neal has published widely in print about the social and political power of Black music. Tara Rogers's Pink Noises is a print project that emerged from pinknoises.com. Regina Bradley's current book project, Chronicling Stankonia: OutKast and the Rise of the Hip Hop South, is in clear dialogue with her digital work. And there are other examples. The Julius Eastman Project, an online legacy project created by composer Mary Jane Leach, cross-fades with various other media, including the print monograph Gay Guerrilla: Julius Eastman and His Music and the CD Unjust Malaise. $\underline{34}$ Data visualizations about Black life, such as "The Atlantic Slave Trade in Two Minutes," rely on a form of visual argumentation with quantitative research that W.E.B. Du Bois experimented with in the late nineteenth century. $\underline{35}$

These examples evince how digital Black Studies is not singular, but part of a broader ecosystem of intellectual thought that increasingly crosses the boundaries of media. Although the modes of distribution have gone digital, this work is highly interconnected with other, more traditional forms of knowledge production. That is, Black Studies in the digital crawlspace builds upon long-established forms of cultural critique and scholarly argumentation. 


\section{Black Studies. Now}

The multiplicity of Black Studies has always offered a way to understand lived experience and a means by which to think about race as a fundamental operating principal of society. It has done so by asking a series of deceptively straightforward questions: What have people done? What are they doing? And what different ways can we think about these actions? The focus on actions and humanity have made the interventions of Black Studies easily portable, even as the modes of creation and distribution continually shift. Like Jacobs, an escape artist who would only "consent not to be a single being," Black Studies refuses singular definition. Its generative quality creates space to recapture the past and imagine new futures. The celebration of Blackness continues to radically redefine what it means to be human, enabling the discovery of alternative modes of being and belonging.

Yet digital spaces have never been safe. So, the crawlspace is a useful way to think about how Black Studies continues to operate through new forms of danger and risk. Projects can and do disappear. Despite its continued online life, pinknoises.com no longer exists in its original form. Individual authors, such as Mary Jane Leach or Mark Anthony Neal, might decide to abandon their digital projects without plans for a lasting archive. Data can be deleted, file formats can go defunct, digital infrastructures can change without warning, and companies can change their search algorithms to redirect away from relevant content. The lack of sustainability, or what Wendy Chun describes as the "enduring ephemeral" of digital knowledge, is fundamental to understanding how knowledge works within the digital crawlspace. $\underline{36}$

Digital ecosystems are unpredictable in other, even more dangerous ways. Anti-Black ideologies inspired by a long history of white supremacy and ethno-nationalism are on the rise around the globe, spreading through digital networks. Public spaces online are being inundated with falsehoods surrounding race, class, ethnicity, gender, and sexuality. $\underline{37}$ Those assumptions quickly move from concept to reality, sometimes in violent ways. $\underline{38}$

Black music continues to operate within this uncomfortable vacillation between possibility and danger. The scholarship surrounding this music nevertheless has power. It can be a joyful reminder that online spaces are overlapping and overflowing with great potential for empathy, understanding, and connection. Even so, Black Studies will always be contested because of its enormous capacity to enact change. Like the 
music of the Black diaspora, Black Studies can be radically allusive. It precisely for this reason that we continue to need Black Studies. Now.

\section{Footnotes}

1. James Weldon Johnson, Writings (New York: Library of America, 2004), 874-75.

2. Chopin's widely performed funeral march is actually Marche funèbre, the third movement of his Piano Sonata No. 2 in B-flat minor. Duke Ellington famously quotes Chopin's march at the end of "Black and Tan Fantasy" (1927), a musical reference and quotation that Byard surely knew. $\subseteq$

3. Charles Mingus, Charles Mingus Sextet with Eric Dolphy: Cornell 1964, Blue Note 09463922102 8, CD, 2007.

4. Fumi Okiji, Jazz as Critique: Adorno and Black Expression Revisited (Stanford: Stanford University Press, 2018), 5. $\doteq$

5. For more on Mingus's music in relation to the political critique of "Fables of Faubus," see Nichole Rustin-Paschal, The Kind of Man I Am: Jazzmasculinity and the World of Charles Mingus Jr. (Middletown: Wesleyan University Press, 2017); Scott Saul, Freedom Is, Freedom Ain't: Jazz and the Making of the Sixties (Cambridge: Harvard University Press, 2003); and Eric Porter, What Is this Thing Called Jazz?: African American Musicians as Artists, Critics, and Activists (Berkeley: University of California Press, 2002). $\leftrightarrows$

6. For more on the cultural history of "Lift Every Voice and Sing," see Imani Perry, May We Forever Stand: A History of the Black National Anthem (Chapel Hill: University of North Carolina Press, 2018). For a related exploration of René Marie's fusion of "Lift Every Voice and Sing" with the "The Star Spangled Banner," see Shana L. Redmond, "Indivisible: The Nation and Its Anthem in Black Musical Performance," Black Music Research Journal 35, no. 1 (2015): 97-118. 7. Erica Ball, "Lift Every Voice and Sing: On the Power of the Black National Anthem," Black Perspectives, July 4, 2019, https://www.aaihs.org/lift-every-voice-andsing-on-black-americas-national-anthem/. Unless otherwise noted, the links cited here were accessed in August 2019. $\subseteq$

8. Mark Anthony Neal develops the notion of the Black musical archive throughout his scholarship. For a clear explanation, see: Mark Anthony Neal, "'Swinging While I'm Singing:' Spike Lee, Public Enemy, and the Message in the Music," Black 
Perspectives, June 24, 2019, https://www.aaihs.org/swinging-while-im-singing-spikelee-public-enemy-and-the-message-in-the-music/. A parallel theorization of Black music as a form of cultural memory can be found in Guthrie Ramsey, Race Music: Black Cultures from Bebop to Hip Hop (Berkeley: University of California Press, 2003), 32-34.

9. Jonathan W. Stone, "Rhetorical Folkness: Reanimating Walter J. Ong in the Pursuit of Digital Humanity," in Digital Sound Studies, ed. Mary Caton Lingold, Darren Mueller, and Whitney Anne Trettien (Durham: Duke University Press, 2018). My exploration of the relationship between Black historical knowledge and digital connectivity is heavily influenced by Stuart Hall, Essential Essays, Vol. 1:

Foundations of Cultural Studies, ed. David Morley (Durham: Duke University Press, 2019), 234-39.

10. Ashleigh Greene Wade, “'New Genres of Being Human': World Making through Viral Blackness," The Black Scholar 47, no. 3 (2017): 33-44.

11. Hazel V. Carby, “It Jus Be's Dat Way Sometime: The Sexual Politics of Women's Blues," in The Jazz Cadence of American Culture, ed. Robert O'Meally (New York: Columbia University Press, 1998): 469-82; Angela Y. Davis, Blues Legacies and Black Feminism: Gertrude "Ma" Rainey, Bessie Smith, and Billie Holiday (New York: Pantheon Books, 1998); Daphne A. Brooks, "Afro-sonic Feminist Praxis: Nina Simone and Adrienne Kennedy in High Fidelity," in Black Performance Theory, ed. Thomas DeFrantz and Anita Gonzalez (Durham: Duke University Press, 2014): 204-22; Farah Jasmine Griffin, If You Can't Be Free, Be a Mystery: In Search of Billie Holiday (New York: Free Press, 2001); Tammy Kernodle, "Having Her Say: The Blues as the Black Woman's Lament," in Woman's Voices Across Musical Worlds, ed. Jane Bernstein (Boston: Northeastern University Press, 2004); Paige A. McGinley, Staging the Blues: From Tent Shows to Tourism (Durham: Duke University Press, 2014). 12. Rustin-Paschal, The Kind of Man I Am, 4-5, 15; Hazel V. Carby, Race Men (Cambridge: Harvard University Press, 1998). $\_$ 13. Although the \#citeblackwomen twitter campaign began in November 2017 as a tshirt made by Christen A. Smith, its analytic intervention has roots in longestablished Black feminism praxis. See Cite Black Women, https://www.citeblackwomencollective.org. $\_$ 
14. One place to begin exploring the literature on race and racism online is: Jessie Daniels, "Race and Racism in Internet Studies: A Review and Critique," New Media $\&$ Society 15, no. 5 (2013): 695-719. Since 2013, this topic has received enormous scholarly attention, some of which I discuss below. $\subseteq$

15. Neal, "'Swinging While I'm Singing.'” Neal quotes Chuck D, who describes the motivation for "Fight the Power" as follows: "New York had a lot of issues and needed an anthem." $\leftrightarrows$

16. Achille Mbembe, Critique of Black Reason, trans. Laurent Dubois (Durham: Duke University Press, 2017). $ヒ$

17. Harriet A. Jacobs, Incidents in the Life of a Slave Girl, ed. R. J. Ellis (Oxford: Oxford University Press, 2015). \pm

18. Fred Moten, Black and Blur (Durham: Duke University Press, 2017), 66-85. My thinking here about resistance and confinement as forms of Black performance is also heavily influenced by Ashon Crawley, "Harriet Jacobs Gets a Hearing," Current Musicology 93 (2012): 35-55. Both Moten and Crawley cite a number of feminist scholars who have also examined Jacobs's writing, including: Saidiya V. Hartman, Scenes of Subjection: Terror, Slavery, and Self-Making in NineteenthCentury America (New York: Oxford University Press, 1997); Hazel V. Carby, Reconstructing Womanhood: The Emergence of the Afro-American Woman Novelist (New York: Oxford University Press, 1987); and Katherine McKittrick, Demonic Grounds: Black Women and the Cartographies of Struggle (Minneapolis: University of Minnesota Press, 2006). $ヒ$

19. Moten, Black and Blur, 67-68. The crawlspace is a reoccurring analytic across Moten's recent work, which includes a trilogy of books that he titled "consent not to be a single being."

20. Hazel Carby analyzes Jacobs's book as a critique against the standards of womanhood and motherhood in relation to white woman (especially in the north). Carby, Reconstructing Womanhood, 46-49. $\_$ 21. McKittrick describes Jacobs's crawlspace (which she describes as a garret) as being situated "in and amongst the violent geographies of slavery" that are defined by the treatment of the racial-sexual body. McKittrick, Demonic Grounds, xxviii. $\triangleq$ 
22. Although I focus here on Black life, my analysis should be read with the knowledge that many other marginalized communities face similar threats and dangers because of their heritage, race, ethnicity, sexual orientation, gender identification, and belief systems. $\subseteq$

23. Many scholars writing at the intersection of Black Studies and critical internet studies have explored this alarming array of issues. Essential reading includes but is not limited to: Safiya Umoja Noble, Algorithms of Oppression: How Search Engines Reinforce Racism (New York: New York University Press, 2018); Ruha Benjamin, Race After Technology: Abolitionist Tools for the New Jim Code (Medford: Polity, 2019); Safiya Umoja Noble and Brendesha M. Tynes, The Intersectional Internet: Race, Sex, Class and Culture Online (New York: Peter Lang, 2016); Virginia Eubanks, Automating Inequality: How High-Tech Tools Profile, Police, and Punish the Poor (New York: St. Martin's Press, 2018); Ruha Benjamin, ed., Captivating Technology: Race, Carceral Technoscience, and Liberatory Imagination in Everyday Life (Durham: Duke University Press, 2019); Cathy O’Neil, Weapons of Math Destruction: How Big Data Increases Inequality and Threatens Democracy (New York: Crown, 2016); Sara Wachter-Boettcher, Technically Wrong: Sexist Apps, Biased Algorithms, and Other Threats of Toxic Tech (New York: W.W. Norton, 2017); and Simone Browne, Dark Matters: On the Surveillance of Blackness (Durham: Duke University Press, 2015). $\subseteq$

24. These issues are explored in: Adam Alter, Irresistible: The Rise of Addictive Technology and the Business of Keeping Us Hooked (New York: Penguin, 2017); Jaron Lanier, Ten Arguments for Deleting Your Social Media Accounts Right Now (New York: Henry Holt, 2018); Cal Newport, Digital Minimalism: Choosing a Focused Life in a Noisy World (New York: Portfolio/Penguin, 2019). 25. For more on the idea of redefining the human in relation to Black Studies and the digital space, see Wade, "New Genres of Being Human"; Kim Gallon, "Making a Case for the Black Digital Humanities" in Debates in the Digital Humanities 2016, ed. Matthew K. Gold and Lauren F. Klein (Minneapolis: University of Minnesota Press, 2016). $\leftrightarrows$

26. Because my focus here is on Black music within the United States, these examples are neither representative nor complete. A full accounting of Black Studies online would require a more international and transnational perspective. $\_$ 
27. Regina N. Bradley, “Outkasted

Conversations," https://www.youtube.com/playlist?list=PLW vBIvUWbvBLBit0-

RT1yK0vqT7KtaXc. Bradley writes about her approach to this project in Regina N. Bradley, "Becoming Outkasted: Archiving Contemporary Black Southernness in a Digital Age," in Digital Sound Studies, ed. Mary Caton Lingold, Darren Mueller, and Whitney Anne Trettien (Durham: Duke University Press, 2018).

28. Regina N. Bradley, "About OutKasted

Conversation," https://www.outkastedconversations.com/about-outkastedconversations/.. \pm

29. Tara Rogers, "Pink Noises," http://www.analogtara.net/wp/projects/pink-noises/.

A link to the Facebook group appears on this website. $\subseteq$

30. One Person, One Vote, http://onevotesncc.org. Black

Perspective, https://www.aaihs.org/black-perspectives/. Black Grooves: Reviews of New Black Music Releases, http://blackgrooves.org. Underlying structures such as WordPress are sometimes outwardly stated and always visible in the page's source code (available in any web browser). $\doteq$

31. Mark Anthony Neal, "Left of Black," https://leftofblack.tumblr.com. Episodes can be easily found through a keyword search. $\_$

32. Neal, "Left of Black." $\doteq$

33. To find article about these topics, search "music" or specific genres on the Black Perspectives homepage, https://www.aaihs.org/black-perspectives/.

34. Mary Jane Leach, "The Julius Eastman

Project," https://www.mjleach.com/eastman.htm. Julius Eastman, Unjust Malaise, New World Records 80638, CD, 2005. Renée Levine Packer, ed., Gay Guerrilla: Julius Eastman and his Music (Rochester: University of Rochester Press, 2018). 35. W.E.B. Du Bois, Whitney Battle-Baptiste, and Britt Rusert, W.E.B. Du Bois's Data Portraits: Visualizing Black America (New York: Princeton Architectural Press, 2018). Andrew Kahn and Jamelle Bouie, "The Atlantic Slave Trade in Two Minutes," Slate, June 25,

2015, http://www.slate.com/articles/life/the history_of american slavery/2015/06/ani mated interactive of the history of the atlantic slave trade.html. This visualization is built using data from the remarkable Slave Voyages, https://www.slavevoyages.org. 
Among its innovations, Slave Voyages includes digitized copies of archival documents, another print-to-digital translation that deserves further theorization. An additional digital project that uses primary source documents in a creative yet critical way is Laurent Dubois, David Garner, and Mary Caton Lingold, Musical Passages, http://www.musicalpassage.org. $\triangleq$

36. Wendy Hui Kyong Chun, "The Enduring Ephemeral, Or the Future is a Memory," Critical Inquiry 35, no. 1 (2008): 148-71. Moreover, the uneven circulating of digital information can exacerbate structural inequality. Todd Wolfson, Jessica Crowell, Camille Reyes, and Amy Bach, "Emancipatory Broadband Adoption: Toward a Critical Theory of Digital Inequality in the Urban United States," Communication, Culture \& Critique 10, no. 3 (2017): 441-59. One project working to solve this issue is the Broadband Research Initiative, supported by the Pew Charitable Trusts, https://www.pewtrusts.org/en/projects/broadband-research-initiative..

37. In her analysis of the website Rap Genius, Bradley relatedly explores how internet anonymity though "ghost annotation" encourages a problematic collapse of social categories around identity. The result, she argues, distances the music (hiphop) from both its socio-cultural conditions and the artistic labor involved in its creation. Regina N. Bradley, "Getting Off at the 13th Floor: Rap Genius and Archiving 21st-Century Black Cultural Memory," Journal of Ethnic American Literature 4, no. 4 (2014): 86-98.

38. Digital connectivity has intensified white extremist ideology, leading to mass murder: twenty dead in El Paso, Texas (2019); fifty-one in Christchurch, New Zealand (2019); eleven in Pittsburgh, Pennsylvania (2018); seventeen in Parkland, Florida (2018); and nine in Charleston, South Carolina (2015). For a clear summary of how these deaths relate to extremist activity online, see Weiyi Cai, Troy Griggs, Jason Kao, Juliette Love and Joe Ward, "White Extremist Ideology Drives Many Deadly Shootings," New York Times, August 4, 2019, https://www.nytimes.com/interactive/2019/08/04/us/white-extremist-activeshooter.html. $\doteq$ 